\section{Oleksandr Kapranov}

Western Norway University of Applied

Sciences, Norway
2018, Vol. 15 (2), 77-99(164)

revije.ff.uni-lj.si/elope

doi: 10.4312/elope.16.1.77-99

UDC: 811.111'243:81'355

\title{
Self-Assessment of the Sounds of the English Language that Pre-Service EFL Teachers Consider Problematic to Pronounce
}

\begin{abstract}
The article presents and discusses a mixed-method study that aimed at establishing how pre-service teachers of English as a Foreign Language (EFL) self-assessed those sounds of the English language that would cause problems for their pronunciation in EFL. Fourteen pre-service EFL teachers on the intermediate level of EFL proficiency whose first language (L1) was Norwegian were recruited for the study. They were asked to write reflective essays concerning the sounds of the English language that they considered problematic to pronounce. The participants' essays were contrasted with the essays written by the control group that was comprised of 14 in-service EFL teachers whose L1 was Norwegian. The results of the analysis revealed that the participants identified several English sounds that they self-assessed as problematic to pronounce, e.g. $/ \mathrm{z} / \mathrm{,} / \mathrm{\delta} /, / \theta /$, and $/ \Lambda /$. The analysis of the controls' essays yielded similar results. These findings and their linguo-didactic implications are discussed in the article.
\end{abstract}

Keywords: English as a Foreign Language (EFL); pre-service EFL teachers; pronunciation; self-assessment; sounds of the English language

\section{Glasovi angleščine, ki jih bodoči učitelji angleščine samoocenjujejo kot težje izgovorljive}

\section{POVZETEK}

Članek predstavlja študijo, ki z mešano metodo ugotavlja, kako bodoči učitelji angleščine kot tujega jezika samoocenjujejo angleške glasove, ki se jim zdijo težje izgovorljivi. V raziskavi sodeluje 14 bodočih učiteljev angleščine na srednji stopnji znanja angleščine, katerih prvi jezik je norveščina. Udeležence smo prosili, naj zapišejo svoje misli o angleških glasovih, ki se jim zdijo težje izgovorljivi. Njihove zapise smo primerjali z zapisi kontrolne skupine, ki jo je sestavljalo 14 učiteljev angleščine kot tujega jezika, katerih prvi jezik je prav tako norveščina. Rezultati razčlembe so razkrili, da so udeleženci našteli več angleških glasov, ki so jih ocenili kot težavne, npr. /z/, /ð/, / $\theta /$ in / / /. Analiza kontrolne skupine je pokazala podoben rezultat. Prispevek razčleni te ugotovitve in njihov jezikovno-didaktični pomen.

Ključne besede: angleščina kot tuji jezik; bodoči učitelji angleščine kot tujega jezika; izgovarjava; samoocenjevanje; glasovi angleščine 


\section{Introduction}

This article presents and discusses a mixed-method study of English sounds that preservice teachers of English as a Foreign Language (EFL) whose first language (L1) is Norwegian consider problematic to pronounce. From a theoretical perspective, this study is embedded into the general theme of the present journal volume, namely the investigation of how the sounds of English are addressed in research, EFL learning and teaching, and self-assessment of pronunciation in EFL. The following two notions are central in the present study: i) self-assessment in the context of foreign language (FL) teaching and learning, and ii) the notion of pronunciation difficulties by EFL students. In the study, self-assessment is regarded as "one's own evaluation of one's performance or capabilities" (Dolosic 2018, 194). The notion of pronunciation difficulties by EFL students is operationalised in this study as a range of those English sounds and suprasegmental units that EFL learners consider challenging to pronounce.

Self-assessment is amply reported in scientific research in education (Boud 2013; Harris 1997; Oscarson 1989) and applied linguistics (Cieślicka and Rojczyk 2017; Dolosic 2018; Kapranov 2015; Lintunen 2013; Saito 2011; Szpyra-Kozłowska 2011; Szyszka 2011). Previous research indicates that self-assessment plays an important role in learning (Boud 2013; Liu and Brantmeier 2019). In this regard, Boud (2013) notes that students are able to self-assess the process and outcomes of their own learning. Self-assessment facilitates the students' awareness of and responsibility for their own learning (Boud 2013; Dlaska and Krekeler 2008; Liu and Brantmeier 2019). Boud (2013) posits that self-assessment involves the development of knowledge and a learner's awareness of the existing standards in the field of learning, as well as the capacity to reflect upon whether or not the learner meets these standards (Boud $2013,12)$. In concert with Boud (2013), Lappin-Fortin and Rye $(2014,301)$ argue that self-assessment is a robust tool in FL teaching and learning, since it appears to increase the students' motivation and FL awareness (Lappin-Fortin and Rye 2014).

A similar approach to self-assessment is proposed by Oscarson (1989), who demonstrates that self-assessment is involved in learning and the students' awareness of learning goals (Oscarson 1989, 3-5). In unison with Oscarson (1989), Dlaska and Krekeler (2008) argue that self-assessment facilitates student-centred learning, provides insight into the learning process, stimulates pro-active learning, and supports students in identifying those sounds of the foreign language that they consider problematic to pronounce (Dlaska and Krekeler 2008, 508). These ideas map onto a definition of selfassessment as "the involvement of students in identifying standards and or criteria to apply to their work and making judgements about the extent to which they have met these criteria and standards" (Boud 2013, 11). In applied linguistics, self-assessment is defined as self-regulatory behaviour that is guided by the students' beliefs concerning how they can control their learning and increased awareness of the learning process of 
their second language (SL) and/or FL (Sweet, Mack, and Olivero-Agney 2019, 177). It should be noted that the terms "self-assessment", "self-evaluation", and "self-ratings" are regarded as synonyms in the present article, in accordance with the prior studies conducted by Boud (2013), and Dlaska and Krekeler (2008).

Self-assessment is associated with a certain number of roles and functions (Boekaerts 1997). In didactics and pedagogy, in particular, self-assessment is regarded as a means of goal-setting, as a constituent part of a language diagnosis system, as well as a part of the learner's portfolio (Oscarson 2013, 2). Following Oscarson (2013), selfassessment in the present study is deemed to be a part of the learner's self-diagnosis system. However, it should be made explicit that self-assessment as a self-diagnosis system is subjective (Szpyra-Kozłowska and Stasiak 2010). As with any subjective judgement, self-assessment is thought to involve inaccuracies and learners' inflated ratings concerning their performance in an FL (Trofimovich et al. 2016).

Extending Oscarson's (2013) approach to self-assessment, it seems reasonable to suggest that self-assessment is characterised by a metacognitive function (Flavell 1979). According to Dettori and Lupi (2013), the metacognitive function of selfassessment is manifested by the learners' knowledge about knowledge, i.e. the learners are able to identify their knowledge gaps, and to distinguish factors and variables that affect the learning outcomes (Dettori and Lupi 2013). From the vantage point of metacognition, self-assessment is seen as "a key learning strategy for autonomous language learning, enabling students to monitor their progress and relate learning to individual needs" (Harris 1997, 12). In relation to EFL oral skills, the metacognitive function of self-assessment is exemplified by the learners' awareness of those individual sounds and/or suprasegmental units that cause difficulties in EFL pronunciation (Dettori and Lupi 2013).

As previously mentioned, another central notion in the present research involves those English sounds that intermediate EFL learners consider difficult to pronounce. Prior literature in applied linguistics and EFL studies indicates that there is a range of variables that are associated with the degree of difficulty that EFL learners might experience in their speech production in EFL (Huang and Radant 2009; Khamkhien 2010; Lintunen 2013; Ohata 2004; Saito 2014; Szpyra-Kozłowska 2011). Specifically, these variables involve the learner's L1, age of acquisition, EFL exposure, phonetic ability, attitude towards the acquisition of correct pronunciation, motivation, and the level of anxiety (Khamkhien 2010; Szyszka 2011). Presumably, these variables, especially the learner's L1, map onto the EFL learner's ability to pronounce the sounds of the English language correctly (Saito 2014). It is inferred from the current research literature that the learner's $\mathrm{L} 1$ is theorised to have a substantial impact upon potential difficulties EFL learners might encounter in terms of pronunciation of certain sounds of the English language (Ohata 2004; Saito 2014). In this regard, Huang and Radant 
(2009) argue that "EFL language learners are likely to encounter difficulties when pronouncing sounds that do not exist in their first language" (Huang and Radant 2009, 116). Specifically, on the intermediate level of EFL proficiency phonetically difficult words and sounds pose significant challenges that involve "intelligibility, comprehensibility, foreign-accentedness and acceptability judgements" (SzpyraKozłowska 2011, 286). Previous research is indicative of the importance of "the proper understanding of the mechanisms that lie behind such serious errors which contribute to the phonetic difficulty of words" (Szpyra-Kozłowska 2011, 287) and individual English sounds that EFL learners tend to associate with difficulties.

Informed by the notions of self-assessment and the English sounds that are potentially difficult to EFL learners, the present study seeks to identify those English sounds that pre-service EFL teachers whose L1 is Norwegian (henceforth - 'participants') consider difficult to pronounce. The identification of the sounds is executed by means of the participants' self-assessment. Given that there is little research on the topic of self-assessment of the English sounds that pose difficulties to pre-service EFL teachers whose L1 is Norwegian (Hopland 2016), this study aims to establish a repertoire of those difficult sounds. Additionally, the study seeks to juxtapose the participants' repertoire of the difficult English sounds with those of the in-service EFL teachers. In particular, a group of in-service EFL teachers whose L1 is Norwegian has been asked to provide expert judgement concerning those English sounds that pose challenges to an average Norwegian L1 EFL learner on the intermediate level of EFL proficiency. The expert judgement approach follows Saito's (2011) methodology "to elicit experienced L2 teachers' opinions to determine learners' problematicity" (Saito 2011, 365). It is hypothesised in the present study that the juxtaposition of the participants' and the in-service EFL teachers' repertoires would be indicative of a range of the English sounds that both these groups subjectively evaluate as problematic and challenging to Norwegian L 1 intermediate EFL learners.

Further, this article is structured as follows. First, I will outline recent research publications that are associated with self-assessment of pronunciation difficulties in EFL by EFL learners from a variety of L1 backgrounds. Second, I will introduce the present study and discuss its findings. Third, the article will be concluded with linguo-didactic implications that would be relevant to the teaching and learning of EFL pronunciation to those EFL learners whose L1 is Norwegian.

\section{Self-Assessment of Pronunciation Difficulties in EFL: Literature Review}

There is a growing line of research that focuses upon the application of self-assessment to the identification of pronunciation difficulties and associated variables experienced by EFL students (Cieślicka and Rojczyk 2017; Kapranov 2015; Lintunen 2013; 
Salimi, Kargar, and Zareian 2014; Szpyra-Kozłowska 2011; Szpyra-Kozłowska and Stasiak 2010; Szyszka 2011). These research studies involve EFL learners whose L1 is Farsi (Salimi, Kargar, and Zareian 2014), Finnish (Lintunen 2013), Korean (Kapranov 2015), and Polish (Cieślicka and Rojczyk 2017; Szpyra-Kozlowska 2011; Szyszka 2011). In particular, Salimi, Kargar and Zareian (2014) aim at establishing a set of difficult English sounds that have been identified by a group of Farsi L1 ELF learners. They argue that Farsi L1 EFL learners predominantly experience problems with the English diphthongs, e.g. /au/ and /əひ/. Additionally, Farsi L1 EFL students consider problematic those consonants that are absent from their L1, e.g. /w/, /ð/, and $/ \theta /$ (Salimi, Kargar, and Zareian 2014).

Similarly to Salimi, Kargar and Zareian (2014), Lintunen (2013) investigates EFL learners' self-assessment of pronunciation problems in English. Lintunen (2013) seeks to compare subjective and objective modes of assessments of Finnish L1 advanced EFL learners' pronunciation in order to establish the connection between self-assessment and the explicit teaching of EFL phonetics. The results of the study by Lintunen (2013) reveal that Finnish L1 EFL learners are aware of their problems associated with EFL pronunciation, and their awareness has increased through teaching. Lintunen (2013) argues that "consonants caused most of the problems for the subjects. The most problematic feature was the phonemic opposition $/ \mathrm{v} /-/ \mathrm{w} /$. In addition, the sibilants (excluding $/ \mathrm{s} /$ ), affricates and dental fricatives were among the most difficult phonemes" (Lintunen 2013, 3-4).

Self-assessment is employed in Kapranov (2015) in order to investigate the evaluation of EFL speech fluency by Korean L1 advanced EFL learners, with the results showing that they self-assess this negatively (Kapranov 2015). The participants in the study (Kapranov 2015) indicate that there are several variables that impede their speech fluency in the English language, e.g. pronunciation, insufficient vocabulary, and limited exposure to EFL speaking contexts. However, the participants do not mention those particular English sounds that might appear problematic to Korean L1 EFL learners (Kapranov 2015).

Self-assessment in relation to pronunciation difficulties experienced by Polish L1 EFL learners is a central concept in the studies conducted by Cieślicka and Rojczyk (2017), Szpyra-Kozłowska (2011), Szpyra-Kozłowska and Stasiak (2010), and Szyszka (2011). In particular, Cieślicka and Rojczyk (2017) examine how Polish L1 EFL learners self-assess their own accent in English. Cieślicka and Rojczyk (2017) suggest that whereas the Polish L1 EFL learners' general self-assessment of their pronunciation and accent is stable, they do not associate their problems with pronunciation with particular English sounds. Similarly to Cieślicka and Rojczyk (2017), Szyszka (2011) has not found any specific English sounds that are seen as problematic by EFL learners. Instead, the participants in Szyszka (2011) indicate that 
the major sources of pronunciation difficulties are associated with the suprasegmental units, consonants, and vowels.

Szpyra-Kozłowska (2011) focuses upon self-assessment of phonetically difficult words by Polish L1 intermediate EFL learners. In particular, the study argues that the contrast /z/-/s/ poses challenges to the Polish L1 EFL learners. In addition, Szpyra-Kozłowska (2011) demonstrates that the learners experience difficulties with high front vowels, i.e. /i:/ and /I/, and several liquids in one word, e.g. "rural", "regularly", etc.

Szpyra-Kozłowska and Stasiak (2010) report a case of self-assessment of English pronunciation by Polish L1 EFL learners who have been exposed to a phonetic training course. Szpyra-Kozłowska and Stasiak (2010) indicate that the learners positively self-assess their correct articulation of various frequent words that they used to mispronounce. Furthermore, the learners' positive self-assessment involves attention to the relationship between English spelling and pronunciation.

As evident from the literature review, there is ample research concerning learners' selfassessment of English sounds and suprasegmentals that account for their difficulties with EFL pronunciation and speech fluency. However, little is known about the self-assessment of difficult-to-pronounce English sounds by pre-service EFL teachers whose L1 is Norwegian. In the following section of the article, I will present a mixedmethod study that addresses and examines this under-researched area.

\section{The Present Study: Its Context and Specific Research Aims}

The present mixed-method study was contextualised within the course in English phonetics offered at a large university in Norway. The course was comprised of lectures and seminars that followed the topics described in the course book "English Phonetics for Teachers" by Nilsen and Rugesæter (2015). The topics that were addressed during the course involved such chapters in the course book as "Sound Foundation", "Consonants", "Vowels", and "The Varieties of Spoken English" (Nilsen and Rugesæter 2015).

Following Cieślicka and Rojczyk (2017), the present study involved an assumption that the participants' reflective essays on the topic "Sounds of the English Language that I Consider Problematic to Pronounce" would be indicative of their difficulties with English pronunciation. Since all participants reported that they assessed their EFL students' pronunciation during teaching practice sessions at school, it was hypothesised that the participants would self-assess their own problems with pronunciation in English. Specifically, it was hypothesised that by means of selfassessment the participants would identify a repertoire of English sounds that would be associated with a degree of difficulty. Concurrently with that assumption, however, it was theorised in the study that the participants' self-assessment could be subjective 
and inflated, as indicated by Trofimovich et al. (2016). Following that contention, it was decided to contrast the participants' self-assessed repertoire of difficult-topronounce English sounds with that of the control group that consisted of in-service EFL teachers. Arguably, the comparison of those two repertoires would facilitate a deeper understanding of self-assessment in relation to those English sounds that were deemed difficult by Norwegian L1 intermediate EFL learners.

Based upon these assumptions, the following specific research aims were formulated:

i) to identify a repertoire of English sounds that were subjectively self-assessed as causing problems in the participants' speech production in EFL;

ii) to identify a repertoire of English sounds that the controls subjectively perceived as posing difficulties to a typical Norwegian L1 EFL learner at the intermediate level of EFL proficiency;

iii) to compare the aforementioned repertoires in order to establish which English sounds would be subjectively perceived as posing difficulties to an intermediate EFL learner whose L1 was Norwegian.

\subsection{Participants}

The participants in the study were 14 EFL university students ( 11 females and three males) who were enrolled in the teacher training programme at a large university in Norway. All participants indicated that Norwegian was their L1 and English was their FL. The participants were deemed to be at an intermediate level of EFL proficiency that was referred to as the English B1 and B2 levels in accordance with the common EU framework of proficiency in a foreign language (The Council of Europe 2011). The participants' mean age at the time of the experiment was 23.5 years. There were no bilinguals among the participants.

The control group consisted of 14 in-service EFL teachers (mean age $=44.5$ years, mean duration of in-service teaching experience $=11.5$ years) who were matched in terms of gender with the group of participants, i.e. 11 females and three males. The controls reported that Norwegian was their L1 and English was their FL. Analogous to the group of participants, there were neither bilinguals nor native speakers of English among the controls.

All participants and their respective controls signed a consent form that allowed the author of the article to analyse their written data for scientific purposes. The participants' and controls' identities were coded to ensure confidentiality. The following codes were used in the study to refer to participants: P and the numbers from 1 to 14, e.g. P1, P2, ... P14. The same coding procedure was applied to the control group. The controls were coded as $\mathrm{C}$ and the numbers from 1 to 14 , e.g. $\mathrm{C} 1, \mathrm{C} 2, \ldots \mathrm{C} 14$. 


\subsection{The Corpus}

The corpus consisted of the participants' and controls' reflective essays. The participants' essays were on the topic "Sounds of the English Language that I Consider Problematic to Pronounce", whereas the controls were requested to write their reflections on the topic "Sounds of the English Language that Norwegian L1 Intermediate EFL Learners Consider Problematic to Pronounce". The application of computer program The Statistical Package for the Social Sciences (SPSS 2016) to the corpus yielded the descriptive statistics summarised in Table 1 below:

TABLE 1. The descriptive statistics of the corpus.

\begin{tabular}{|l|l|c|c|}
\hline $\mathrm{N}$ & Measure & Participants & Controls \\
\hline 1 & Total Number of Words & 4299 & 5586 \\
\hline 2 & M Words & 307 & 399 \\
\hline 3 & STD & 48 & 167 \\
\hline 4 & Minimum & 197 & 228 \\
\hline 5 & Maximum & 392 & 923 \\
\hline
\end{tabular}

$\mathrm{M}=$ mean; $\mathrm{STD}=$ standard deviation .

\subsection{Procedure and Method}

The procedure in the study involved the following steps. First, the participants were asked to write reflective essays of approximately 300 words on the topic "Sounds of the English Language that I Consider Problematic to Pronounce". The controls were instructed to write reflective essays of 300 words on the topic "Sounds of the English Language that Norwegian L1 Intermediate EFL Learners Consider Problematic to Pronounce". It should be emphasised that the controls did not reflect on their own problems with the English sounds. Instead, they were specifically instructed to write their reflections on the possible range of English sounds that they thought would pose problems for an intermediate EFL learner whose L1 was Norwegian. The participants and their controls were given one week to write the essays. The participants and controls delivered their reflective essays to the author of this article via e-mail.

In addition to the reflective essay, the participants were asked to transcribe two short texts in IPA, one text a month prior to the writing of the essay (see Text 1 below) and another text (see Text 2 in this subsection) one month after the essay. The participants were expected to use the so-called broad IPA transcription that presupposed that allophonic nuances (for instance, the dark /1/) could be omitted and/or ignored. The participants were given one week to transcribe each text, thus making it two weeks in total for the IPA transcription task. The participants were allowed to use 
pronunciation dictionaries, study aids, and the Internet in this task. The final task the participants were asked to execute was the sit-in exam in English linguistics that involved functional grammar and phonetics. At the exam, the participants were instructed to transcribe a short text in English (see Text 3 below) in IPA without any study aids, e.g. dictionaries, the course book, and online resources. The exam's duration was approximately 6 hours.

Text 1. In 1904 an earthquake of magnitude 5.4 on the Richter scale shook Oslo, with an epicenter in the "Oslo Graben" which runs under the Norwegian capital. There are now signs that indicate that we can expect a major future earthquake in Oslo (IMDB 2018a).

Text 2. From the outer reaches of space to the small-town streets of suburbia, the hunt comes home. Now, the universe's most lethal hunters are stronger, smarter and deadlier than ever before, having genetically upgraded themselves with DNA from other species. When a young boy accidentally triggers their return to Earth, only a ragtag crew of ex-soldiers and a disgruntled science teacher can prevent the end of the human race (IMDB 2018b).

Text 3. Once upon a time, there was a famous musician. He met Anna, a struggling artist, who gave up on her dream to make it big as a singer. However, the famous musician decided to make her known all over the world. He wrote songs for her and went on tour with her. Soon, Anna's career took off and she became famous in North America (IMDB 2018c).

Texts 1-3 were chosen for transcription in IPA based upon the following criteria: i) suitability. In particular, the texts were deemed suitable taking into consideration that they contained all English consonants and vowels; ii) an understandable topic that the participants could relate to. As pointed by Thomas (2014), EFL materials should be authentic, relevant, and understandable. All three texts chosen for transcription in IPA were film plot summaries taken from the Internet Movie Database (IMDB) site. Following Thomas (2014), film summaries were thought to be understandable and relevant to the participants.

The participants' reflective essays were manually examined by the author of this article for the explicit presence of those sounds that the participants self-assessed as posing problems and difficulties as far as their pronunciation in the English language was concerned. Similarly, the controls' reflective essays on the topic "Sounds of the English Language that Norwegian L1 Intermediate EFL Learners Consider Problematic to Pronounce" were manually investigated for the presence of the English sounds that the controls deemed problematic for an intermediate EFL learner whose L1 was Norwegian. The participants' IPA transcriptions were 
examined by the author of the article and by a lecturer in English, who served on the examiner's board at a large university in Norway. The lecturer confirmed the results of the error analysis.

\subsection{Results}

The results of the mixed methods analysis yielded descriptive statistics that were summarised in Tables 2-7. In particular, Table 2 involved a summary of the participants' self-assessed problematic sounds and the objective error analysis of the IPA assignments by the course teacher.

TABLE 2. The participants' self-assessment of problematic sounds and the objective error analysis of the IPA assignments by the course teacher.

\begin{tabular}{|c|c|c|c|c|c|}
\hline $\mathbf{N}$ & $\mathbf{P}$ & \begin{tabular}{|l|} 
Self-Assessed \\
Problematic \\
Sounds \\
\end{tabular} & $\begin{array}{l}\text { Errors in IPA } \\
\text { Assignment } 1\end{array}$ & \begin{tabular}{|l} 
Errors in IPA \\
Assignment 2
\end{tabular} & \begin{tabular}{|l} 
Errors in IPA \\
Assignment 3
\end{tabular} \\
\hline 1 & P 1 & $/ \partial / / \theta / / \mathrm{w} /$ & - & - & - \\
\hline 2 & P 2 & 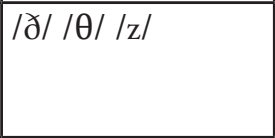 & $/ ð /$ instead of $/ \theta /$ & - & $\begin{array}{l}/ \mathrm{s} / \text { instead of } / \mathrm{z} / \\
/ \mathrm{a}: / \text { instead of } / \mathfrak{x} / \\
/ \mathrm{a} / \text { instead of } / \mathrm{e} /\end{array}$ \\
\hline 3 & P 3 & $/ \mathrm{z} / / \mathrm{\partial} / / \mathrm{t} \int /$ & $\begin{array}{l}\mathrm{\Lambda} / \text { instead of } / \mathrm{\partial} / \\
/ \mathfrak{x} / \text { instead of } / \mathrm{\partial} /\end{array}$ & $\begin{array}{l}/ \mathrm{s} / \text { instead of } / \mathrm{z} / \\
/ \Lambda / \text { instead of } / \mathrm{a} / \\
/ \mathrm{p} / \text { instead of } / \mathrm{a} /\end{array}$ & $\begin{array}{l}\mathrm{a}: / \text { instead of } / \mathrm{a} / \\
/ \mathrm{s} / \text { instead of } / \mathrm{z} / \\
/ \mathrm{L} / \text { instead of } / \mathrm{\partial} / \\
/ \mathrm{\partial} / \text { instead of } / \theta /\end{array}$ \\
\hline 4 & P 4 & $\begin{array}{l}|\Lambda /| z / / s / / \partial / / \theta / \\
/ \partial /\end{array}$ & $/ \Lambda /$ instead of $/ \partial /$ & - & $/ \mathrm{s} /$ instead of $/ \mathrm{z} /$ \\
\hline 5 & P 5 & $/ \mathrm{z} / / \mathrm{t} \int / / \mathrm{J} / / \partial / / \theta /$ & $/ \theta /$ instead of /ð/ & - & $\begin{array}{l}\Lambda / \text { instead of } / \partial / \\
/ \mathrm{u} / \mathrm{i} \text { instead of } / \mathrm{\partial} / \\
/ \mathrm{\partial} / \text { instead of } / \mathrm{e} /\end{array}$ \\
\hline 6 & P 6 & $/ \theta / / z /$ & - & - & /u:/ instead of /ə/ \\
\hline 7 & P 7 & $/ \theta / / \mathrm{z} / / \mathrm{w} /$ & $\begin{array}{l}/ \theta / \text { instead of } / \partial / \\
/ \Lambda / \text { instead of } / \partial /\end{array}$ & $\begin{array}{l}/ \theta / \text { instead of } / ð / \\
/ \mathrm{p} / \text { instead of } / \mathrm{\partial} /\end{array}$ & $\begin{array}{l}\mathrm{z} / \text { instead of } / \mathrm{s} / \\
/ \mathrm{s} / \text { instead of } / \mathrm{z} /\end{array}$ \\
\hline 8 & P 8 & $|\theta /| \mathrm{z} /$ & - & - & $\begin{array}{l}/ \mathrm{s} / \text { instead of } / \mathrm{z} / \\
/ \mathrm{\Lambda} / \text { instead of } / \mathrm{a} / \\
/ \mathrm{\partial} / \text { instead of } / \mathrm{e} /\end{array}$ \\
\hline 9 & P 9 & $|\mathrm{z}|$ & $/ \Lambda /$ instead of $/ \partial /$ & - & $\begin{array}{l}/ \mathrm{v} / \text { instead of } / \mathrm{w} / \\
/ \mathrm{z} / \text { instead of } / \mathrm{s} / \\
/ \mathrm{L} / \text { instead of } / \mathrm{a} / \\
/ \mathrm{s} / \text { instead of } / \mathrm{z} / \\
/ \mathrm{v} / \text { instead of } / \mathrm{\partial} /\end{array}$ \\
\hline 10 & P 10 & $\mid \mathrm{z} / / \mathrm{s} /$ & $\begin{array}{l}\mathrm{s} / \text { instead of } / \mathrm{z} / \\
/ \mathrm{w} / \text { instead of } / \mathrm{\partial} /\end{array}$ & $/ \mathrm{p} /$ instead of /ə/ & $\begin{array}{l}\mathrm{z} / \text { instead of } / \mathrm{s} / \\
/ \mathrm{a}: / \text { instead of } / \mathrm{a} /\end{array}$ \\
\hline 11 & P 11 & $\mid \mathrm{z} / / \mathrm{\partial} /$ & \begin{tabular}{|l|}
$/ \mathrm{v} /$ instead of $/ \mathrm{\partial} /$ \\
$/ \mathrm{\partial} /$ instead of $/ \theta /$
\end{tabular} & $\begin{array}{l}/ \mathrm{s} / \text { instead of } / \mathrm{z} / \\
/ \mathrm{w} / \text { instead of } / \mathrm{a} /\end{array}$ & $\begin{array}{l}\mathrm{z} / \text { instead of } / \mathrm{s} / \\
/ \mathrm{L} / \text { instead of } / \mathrm{\partial} /\end{array}$ \\
\hline
\end{tabular}




\begin{tabular}{|c|c|c|c|c|c|}
\hline 12 & P 12 & $/ \theta / / \mathrm{w} / \mathrm{z} / / \mathrm{s} /$ & - & $/ \mathrm{z} /$ instead of $/ \mathrm{s} /$ & $\begin{array}{l}/ \mathrm{z} / \text { instead of } / \mathrm{s} / \\
/ \Lambda / \text { instead of } / \partial / \\
/ \partial / \text { instead of } / \mathrm{e} /\end{array}$ \\
\hline 13 & P 13 & $/ \theta / / \mathrm{z} / / \mathrm{s} /$ & $/ \mathrm{p} /$ instead of /ə/ & - & $\begin{array}{l}/ \Lambda / \text { instead of } / \partial / \\
/ \mathrm{s} / \text { instead of } / \mathrm{z} / \\
/ \mathrm{z} / \text { instead of } / \mathrm{s} /\end{array}$ \\
\hline 14 & P 14 & $\begin{array}{l}\text { ठ/ / } / \mathrm{l} / \mathrm{s} / \mathrm{z} / \mathrm{lv} / \\
/ \mathrm{w} /\end{array}$ & $/ \mathrm{p} /$ instead of /ə/ & $/ \Lambda /$ instead of /ə/ & $\begin{array}{l}/ \mathrm{v} / \text { instead of } / \mathrm{w} / \\
/ \Lambda / \text { instead of } / \partial / \\
/ \mathrm{a}: / \text { instead of } / x / \\
/ \mathrm{a} / \mathrm{instead} \text { of } / \mathrm{\partial} /\end{array}$ \\
\hline
\end{tabular}

Explanation of the abbreviations: $\mathrm{P}=$ participant.

In addition to the difficult English sounds that were self-assessed by the participants, Table 2 was comprised of the participants' errors in three IPA transcription tasks. Those tasks are referred to as Assignment 1, Assignment 2, and Assignment 3 in Table 2. It should be reiterated that the execution of Assignments 1-2 involved two weeks of preparation at home with the use of all available study aids, whilst Assignment 3 was an unprepared part of the sit-in exam without any access to course books, study materials, or the Internet.

In contrast to the group of participants, the controls were instructed to write their reflective essays upon those English sounds that would typically cause problems for a Norwegian EFL learner at the intermediate level of EFL proficiency, i.e. the controls did not reflect upon their own problems with the difficult-to-pronounce English sounds. The results of the corpus of the reflective essays written by the controls are presented in Table 3.

TABLE 3. The controls' assessment of the sounds of the English language that pose problems for Norwegian L1 intermediate EFL learners.

\begin{tabular}{|l|l|l|}
\hline $\mathbf{N}$ & Controls & $\begin{array}{l}\text { English Sounds that Cause Problems for Norwegian L1 } \\
\text { Intermediate EFL Learners }\end{array}$ \\
\hline 1 & C 1 & $/ / / / \theta / / \mathrm{w} /$ \\
\hline 2 & C 2 & $/ \partial / / \theta /$ \\
\hline 3 & C 3 & $/ \mathrm{d} / / \theta / / \mathrm{z} /$ \\
\hline 4 & C 4 & $/ \mathrm{z} / / \mathrm{t} / / \mathrm{\partial} /$ \\
\hline 5 & C 5 & $/ \mathrm{z} / / \mathrm{s} / / \mathrm{d} / / \theta /$ \\
\hline 6 & C 6 & $/ \mathrm{z} / / \theta / / \mathrm{t} /$ \\
\hline 7 & C 7 & $/ \theta / / \mathrm{z} / / \mathrm{w} /$ \\
\hline 8 & C 8 & $/ \theta / / \mathrm{z} / / \mathrm{w} / / \mathrm{v} /$ \\
\hline 9 & C 9 & $/ \theta / / \mathrm{z} / / \mathrm{w} /$ \\
\hline 10 & C 10 & $/ \mathrm{z} / / \mathrm{s} / / \mathrm{d} / / \theta /$ \\
\hline
\end{tabular}




\begin{tabular}{|l|l|l|}
\hline 11 & C 11 & $/ \mathrm{z} / / \mathrm{\partial} / / \mathrm{\partial} / / \theta /$ \\
\hline 12 & $\mathrm{C} 12$ & $/ \mathrm{z} / / \mathrm{s} / / \mathrm{w} /$ \\
\hline 13 & $\mathrm{C} 13$ & $/ \mathrm{\partial} / / \theta / / \mathrm{s} / / \mathrm{z} / \mathrm{v} / / \mathrm{w} /$ \\
\hline 14 & $\mathrm{C} 14$ & $/ \mathrm{\partial} / / \theta / / \mathrm{s} / / \mathrm{z} /$ \\
\hline
\end{tabular}

The mean number of sounds that caused problems for Norwegian L1 intermediate EFL learners is summarised in Table 4 below.

TABLE 4. Sounds that caused problems for Norwegian L1 intermediate EFL learners (by group).

\begin{tabular}{|l|l|l|l|}
\hline $\mathbf{N}$ & Measure & Participants & Controls \\
\hline 1 & $\begin{array}{l}\text { M sounds that cause prob- } \\
\text { lems for intermediate EFL } \\
\text { Learners whose L1 is Nor- } \\
\text { wegian (per group) }\end{array}$ & 3.5 \\
\hline 2 & STD & 1.5 & 1 \\
\hline
\end{tabular}

$\mathrm{M}=$ mean; $\mathrm{STD}=$ standard deviation.

The percentages of those English sounds that were given in Tables 2-3 was calculated in SPSS (2016), and the results are presented in Table 5.

TABle 5. The Percentages for the difficult sounds that the participants and controls consider problematic for Norwegian L1 intermediate EFL learners.

\begin{tabular}{|l|l|l|l|}
\hline $\mathbf{N}$ & Difficult Sound & Participants & Controls \\
\hline 1 & $/ \mathrm{\Lambda} /$ & $7 \%$ & - \\
\hline 2 & $/ \mathrm{a} /$ & $21 \%$ & $14 \%$ \\
\hline 3 & $/ \mathrm{s} /$ & $36 \%$ & $36 \%$ \\
\hline 4 & $/ \mathrm{J} /$ & $7 \%$ & - \\
\hline 5 & $/ \mathrm{t} /$ & $14 \%$ & $14 \%$ \\
\hline 6 & $/ \mathrm{\partial} /$ & $50 \%$ & $57 \%$ \\
\hline 7 & $/ \theta /$ & $71 \%$ & $86 \%$ \\
\hline 8 & $/ \mathrm{v} /$ & $7 \%$ & $14 \%$ \\
\hline 9 & $/ \mathrm{w} /$ & $29 \%$ & $43 \%$ \\
\hline 10 & $/ \mathrm{z} /$ & $93 \%$ & $86 \%$ \\
\hline
\end{tabular}

Tables 6-7 outlined the participants' mean number of errors (Table 6) and the percentage of errors per group (Table 7) in the IPA transcription tasks.

TABLE 6. Errors in IPA transcription tasks performed by the participants

\begin{tabular}{|l|l|l|l|l|}
\hline $\mathbf{N}$ & Measure & $\begin{array}{l}\text { Errors in IPA } \\
\text { Assignment 1 }\end{array}$ & $\begin{array}{l}\text { Errors in IPA } \\
\text { Assignment 2 }\end{array}$ & $\begin{array}{l}\text { Errors in IPA } \\
\text { Assignment 3 }\end{array}$ \\
\hline 1 & $\begin{array}{l}\text { M errors per group } \\
\text { in the task }\end{array}$ & 1 & 0.7 & 2.6 \\
\hline 2 & STD & 0.8 & 1 & 1.3 \\
\hline
\end{tabular}

$\mathrm{M}=$ mean; $\mathrm{STD}=$ standard deviation 
TABLE 7. The percentage of errors per group of participants in the IPA transcription tasks.

\begin{tabular}{|c|c|c|c|c|}
\hline $\mathbf{N}$ & Error & $\begin{array}{l}\text { Percentage of } \\
\text { Errors in IPA } \\
\text { Assignment } 1 \\
\end{array}$ & $\begin{array}{l}\text { Percentage of } \\
\text { Errors in IPA } \\
\text { Assignment } 2\end{array}$ & $\begin{array}{l}\text { Percentage of } \\
\text { Errors in IPA } \\
\text { Assignment } 3 \\
\end{array}$ \\
\hline 1 & $/ \Lambda /$ instead of $/ \partial /$ & $29 \%$ & $14 \%$ & $50 \%$ \\
\hline 2 & /a:/ instead of /æ/ & - & - & $14 \%$ \\
\hline 3 & /a:/ instead of /ə/ & - & - & $21 \%$ \\
\hline 4 & $/ æ /$ instead of /ə/ & $7 \%$ & - & - \\
\hline 5 & /ə/ instead of /e/ & - & - & $29 \%$ \\
\hline 6 & $/ \mathrm{p} /$ instead of /ə/ & $29 \%$ & $29 \%$ & - \\
\hline 7 & $/$ s/ instead of $/ z /$ & $7 \%$ & $14 \%$ & $50 \%$ \\
\hline 8 & $/$ / instead of $/ \theta /$ & $14 \%$ & - & $7 \%$ \\
\hline 9 & $/ \theta /$ instead of /ð/ & $14 \%$ & $7 \%$ & - \\
\hline 10 & /u:/ instead of /ə/ & - & - & $14 \%$ \\
\hline 11 & $/ \mho /$ instead of /ə/ & - & - & $7 \%$ \\
\hline 12 & $/ \mathrm{v} /$ instead of $/ \mathrm{w} /$ & - & - & $14 \%$ \\
\hline 13 & /z/ instead of /s/ & - & $7 \%$ & $43 \%$ \\
\hline
\end{tabular}

Table 8 and Table 9 below illustrate the participants' and controls' explanations and comments in the reflective essays that concerned the causes of the difficulties associated with the problematic English sounds.

TABLE 8. The participants' comments and explanations concerning the causes of difficulties associated with the English sounds.

\begin{tabular}{|c|c|c|}
\hline $\mathbf{N}$ & Participants & The Participants' Comments and Explanations \\
\hline 1 & P1 & "There is no similar English sound in Norwegian." \\
\hline 2 & P2 & - \\
\hline 3 & P3 & "Differences between the native language and English..." \\
\hline 4 & P4 & "The difficult English sound is never used in Norwegian." \\
\hline 5 & P5 & $\begin{array}{l}\text { "The sounds that are difficult for Norwegian learners of English } \\
\text { as a foreign language are typically sounds that are not used in the } \\
\text { Norwegian language." }\end{array}$ \\
\hline 6 & P6 & - \\
\hline 7 & P7 & $\begin{array}{l}\text { "...the main reason for this is that we do not have the same or } \\
\text { similar sounds in the Norwegian language. The /z/ sound can be a } \\
\text { good example of this. This is a sound we do not use in Norwegian." }\end{array}$ \\
\hline 8 & P8 & - \\
\hline 9 & P9 & $\begin{array}{l}\text { "The first sound in English that I struggle with is the /z/ sound. It } \\
\text { is a sound we don't really use in Norwegian." }\end{array}$ \\
\hline 10 & P10 & $\begin{array}{l}\text { "I think it's sometimes difficult to pronounce words that start with } \\
\text { /v/ or /w/ because they sound like the same." }\end{array}$ \\
\hline
\end{tabular}




\begin{tabular}{|l|l|l|}
\hline 11 & P11 & $\begin{array}{l}\text { "One of the sounds most Norwegians, myself included, struggle } \\
\text { with is the sound } / z / . \text { This is due to the fact that /z/ doesn't appear } \\
\text { in the Norwegian language." }\end{array}$ \\
\hline 12 & P12 & $\begin{array}{l}\text { "English has different pronunciation and sounds which we cannot } \\
\text { find in the Norwegian language. Thus, there are some sounds I find } \\
\text { more difficult than others." }\end{array}$ \\
\hline 13 & P13 & $\begin{array}{l}\text { "Most of the sounds that can challenge a Norwegian language } \\
\text { learner of English are sounds that don't exist in the Norwegian } \\
\text { language." }\end{array}$ \\
\hline 14 & P14 & $\begin{array}{l}\text { "The one that I struggle the most with is /q/. I think I find this } \\
\text { sound really difficult to pronounce is probably because it is not } \\
\text { used in Norwegian." }\end{array}$ \\
\hline
\end{tabular}

It should be noted that whereas Table 8 presented the participants' comments concerning their own problems and difficulties with the sounds of the English language and possible causes of these, the controls' comments summarised in Table 9 concerned intermediate EFL learners (in other words, in Table 9 the controls did not comment on the variables that caused problems with pronunciation to themselves).

TABLE 9. The controls' comments and explanations concerning the causes of difficulties associated with English sounds.

\begin{tabular}{|c|c|c|}
\hline $\mathbf{N}$ & Participants & The Controls' Comments and Explanations \\
\hline 1 & $\mathrm{C} 1$ & $\begin{array}{l}\text { "...my students tend not to round their lips when pronouncing } \\
\text { an English } / \text { w/ as in why, were, when. Instead they use the Nor- } \\
\text { wegian } / \mathrm{v} / \text {. Again, it is said to be a Norwegian problem." }\end{array}$ \\
\hline 2 & $\mathrm{C} 2$ & $\begin{array}{l}\text { "Norwegians often seem to use Norwegian articulation when } \\
\text { they speak English." }\end{array}$ \\
\hline 3 & $\mathrm{C} 3$ & $\begin{array}{l}\text { "One of the sounds my students find most problematic is } / z / \text {. I } \\
\text { think it is a difficult sound to pronounce. We do not have that } \\
\text { sound in the Norwegian language." }\end{array}$ \\
\hline 4 & $\mathrm{C} 4$ & - \\
\hline 5 & $\mathrm{C} 5$ & - \\
\hline 6 & C6 & $\begin{array}{l}\text { "A common mistake is to substitute the sound /ð/ with } / \mathrm{d} / . \text { A } \\
\text { reason that many Norwegians find this sound difficult to pro- } \\
\text { nounce could be that the sound /ð/ is a dental fricative, and } \\
\text { there are no dental fricatives in the Norwegian language..." }\end{array}$ \\
\hline 7 & $\mathrm{C} 7$ & $\begin{array}{l}\text { "The English dental fricative sounds } / \theta / \text { and } / \partial / \text { are sounds we } \\
\text { don't find in the Norwegian language, so the students find them } \\
\text { hard to pronounce..." }\end{array}$ \\
\hline 8 & C8 & - \\
\hline 9 & C9 & $\begin{array}{l}\text { "Many Norwegian learners find it difficult to pronounce dental } \\
\text { fricatives. In the Norwegian language, there are no dental frica- } \\
\text { tives when it comes to consonants." }\end{array}$ \\
\hline 10 & $\mathrm{C} 10$ & - \\
\hline
\end{tabular}




\begin{tabular}{|l|l|l|}
\hline 11 & C11 & $\begin{array}{l}\text { "I think that eloquent examples of difficult sounds come from } \\
\text { words which are written in a completely different way than they } \\
\text { are pronounced." }\end{array}$ \\
\hline 12 & $\mathrm{C} 12$ & - \\
\hline 13 & $\mathrm{C} 13$ & $\begin{array}{l}\text { " } \\
\text { that in students tend to mix /v/ and /w/. The reason for this is } \\
\text { same way as those spelt with 'v." }\end{array}$ \\
\hline 14 & $\mathrm{C} 14$ & $\begin{array}{l}\text { "... } \\
\text { it is a difficult sound to pronounce. We do not have that sound } \\
\text { in the Norwegian language." }\end{array}$ \\
\hline
\end{tabular}

\subsection{Discussion}

As previously mentioned, it has been assumed in the study that the participants would self-assess their pronunciation difficulties associated with the sounds of the English language. The assumption involves the fact that the participants are preservice EFL teachers who have experienced several sessions of teaching practice at school. Consequently, it has been hypothesised that the participants would use their assessment skills they might possess as pre-service EFL teachers in order to self-assess their own problems with pronunciation in English. The results of the analysis of the participants' reflective essays are indicative of the repertoire of English sounds that the participants associate with a degree of difficulty. As evident from Table 2 and Table 5, the participants' repertoire of self-assessed difficult sounds in English

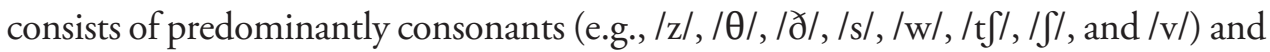
monophthongs (e.g., ///, / $/ /$ ).

As seen in the data summarised in Table 5, the participants' most problematic sounds in the English language, e.g. /z/ (93\%), / $/$ / (71\%), and / $/$ / (50\%), are absent from their L1, Norwegian. In order to illustrate these findings, let us consider the following excerpt written by one of the participants.

(1) The sounds that are difficult for Norwegian learners of English as a foreign language are typically sounds that are not used in the Norwegian language. Personally I have struggled with following phonemes: $/ \theta /, / \mathrm{z} /, / \mathrm{w} /$ and $/ \mathrm{v} / \ldots / \theta /$ as in three is a difficult sound because it does not exist in the Norwegian language. We have similar sounds, $/ \mathrm{t} /$ and $/ \mathrm{f} /$, and it is easy to replace the $/ \theta /$ with one of these sounds. $/ \mathrm{z} /$ as in quiz is a difficult sound for the same reason as the $/ \theta /$ : It simply does not exist in the Norwegian language. Norwegian students (including me) usually replace it with an $/ s /$. What I find interesting is that the /z/ sound is usually not difficult to produce, but it is easily forgotten. Another difficult sound found in the word quiz is the $/ \mathrm{w} /$. Since $/ \mathrm{w} /$ is not found in the Norwegian language either, it is usually replaced with a $/ \mathrm{v} /$. As a result we end up with quiz being pronounced as [kvis]. (Participant P 5, female) 
Excerpt (1) and the findings in Table 5 support the literature (Ohata 2004; Saito 2014) that emphasises the role of the learners' L1 in their ability to pronounce English sounds of the English language correctly (Saito 2014). The analysis of the reflective essays written by the controls provides further support for the role of the Norwegian language in the learners' difficulties with the English sounds. Specifically, the controls and participants assess as difficult those sounds that are absent from the phonological system of the Norwegian language (e.g., /z/, / $\theta /, / ð /, / \mathrm{w} /$, and /ə/), as well as the contrasts $/ \mathrm{s} /-\mathrm{z} /$ and $/ \mathrm{v} /-/ \mathrm{w} /$. These findings appear to be in concert with the prior research by Lintunen (2013), who finds that Finnish L1 EFL learners' difficulties with the English sounds involve the phonemic opposition /v/-/w/ (Lintunen 2013, 3). Whereas Finish is not an Indo-European language, both Finnish and Norwegian lack a bilabial sound that is analogous to the sound $/ \mathrm{w} /$ in the English language. It is inferred from Lintunen (2013) that the difficulties with the contrasts such as /v/-/w/ are associated with the typological distance between Finnish and English.

Similar to the observations found in Lintunen (2013), five out of 14 controls (36\%) indicate that the main cause of the Norwegian L1 EFL learners' difficulties is associated with those English sounds that have no equivalents in the Norwegian language. It is evident from Table 8 and Figure 1 below that the majority of the participants (71\%) share the same assumption concerning the cause of their difficulties with certain English sounds.

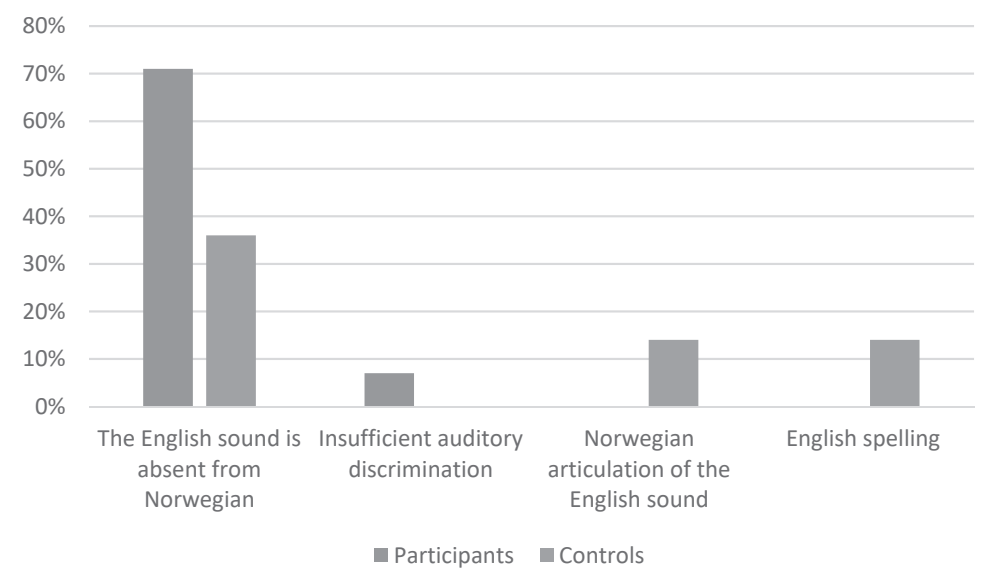

FigURE 1. The causes of difficulties of problematic sounds according to the participants and controls.

Arguably, the findings shown in Figure 1 support previous studies that suggest that EFL learners "encounter difficulties when pronouncing sounds that do not exist in their first language" (Huang and Radant 2009, 116). These findings are further illustrated by excerpt 2 , where a control indicates the following: 
(2) As an English teacher, I notice some difficulties that many Norwegian students, and adults, have. A person with a typical bad "Norwegian-English" or a student who starts to learn English often has difficulties with the sound $/ \partial /$. A common mistake is to substitute the sound / $/ /$ with $/ \mathrm{d} /$. A reason that many Norwegians find this sound difficult to pronounce could be that the sound / $/$ / is a dental fricative, and there are no dental fricatives in the Norwegian language... (Control C 6, female)

Whereas the participants (71\%) and controls (36\%) attribute the causes of difficult English sounds to the fact that these do not exist in the Norwegian language, the data analysis indicates that $14 \%$ of the controls appear to associate the causes of difficulties with the English spelling conventions. In addition, 14\% of the controls suggest that Norwegian L1 learners of English use typical Norwegian articulation to produce English sounds. In contrast to the control group, the participants do not refer to articulation and spelling as the source of the difficulties associated with the English sounds. Notably, the participants do not make explicit comments concerning their problems with the transcription of the English texts in IPA (see Table 2 and Table 7). Presumably, the English spelling could have triggered errors in IPA transcriptions (see Table 2). However, it does not follow from the data that the participants seem to be aware of the English spelling as a variable involved in their difficulties with certain English sounds. Obviously, the correlation between the spelling and pronunciation difficulties merits further attention. However, it is beyond the scope of the present study to offer scientific generalisations concerning this issue, since it has not been referred to by the participants. Whereas the participants do not identify the English spelling as cause of their difficulties, $7 \%$ of them point to insufficient auditory discrimination as a cause of difficulties associated with the certain English sounds. In particular, one participant writes in her reflective essay that "I think it's sometimes difficult to pronounce words that start with /v/ or /w/ because they sound the same" (Participant P 10, female).

As previously mentioned, the controls provided their expert judgements in order to determine intermediate EFL learners' problematicity in the sense postulated by Saito (2014; 2011). Notably, it is evident from Tables 2-7 that the participants and their respective controls share a common view concerning a range of English sounds that are deemed to be problematic. The participants' self-assessment and the controls' expert judgements are illustrated by Figure 2 below.

As seen in Figure 2, the English consonant sounds /z/, / $/ /, / \partial /$, and $/ \mathrm{w} /$ are perceived as the most problematic by the participants and controls. The high occurrence of these sounds is explicable by the absence of these or analogous sounds in the Norwegian language. These findings lend support to the previous research literature that emphasises the connection between the problematicity of an English sound for EFL learners and the learners' L1 (Lintunen 2013; SzpyraKozłowska 2011). 


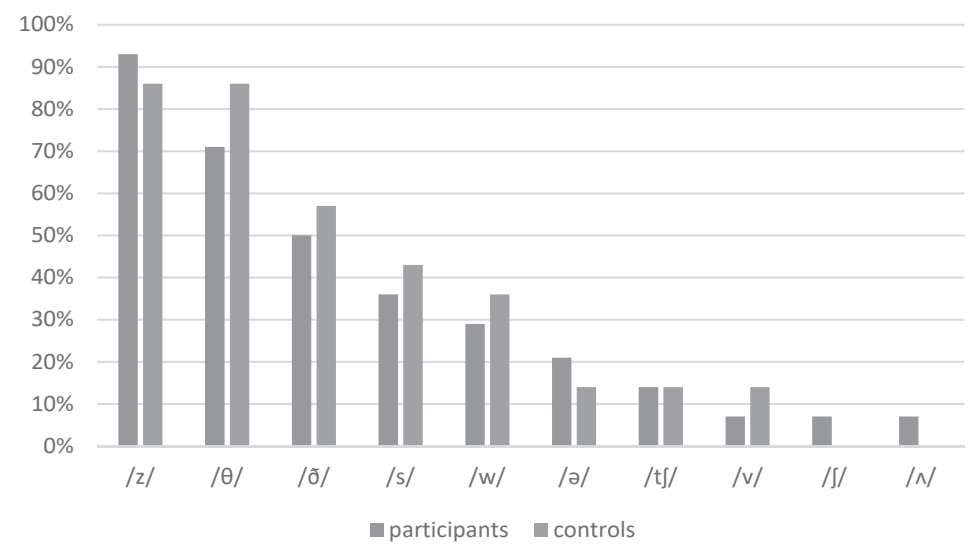

Figure 2. Difficult sounds in English according to the participants and the controls.

It is evident from Figure 2 that the participants self-assess the voiced fricative consonant $/ \mathrm{z} /$ as one of the most difficult English sounds. This finding supports previous research by Lintunen (2013) and Szpyra-Kozłowska (2011), who find that the contrast $/ z /-/ s /$ poses challenges to Finnish L1 and Polish L1 EFL learners, respectively. Moreover, the present findings provide indirect support to previous research that involves heritage speakers of Norwegian who reside in the USA (Haugen 1969; Moen 1988). Specifically, Moen (1988) reports a considerable number of errors related to the English fricative consonant /z/. Moen (1988) indicates that $46 \%$ of the first and second generation Norwegian Americans in the study substitute /z/ for $/ s /$ in their oral communication in English.

The participants' subjective assessments of the voiced fricative consonant $/ \mathrm{z} / \mathrm{as}$ a difficult sound are reflected in the objectively rated IPA transcription tasks, where the participants make a substantial number of mistakes that involve /z/. This finding is further exemplified by Figure 3 that illustrates the participants' selfassessment of the problematicity associated with the English consonant sound $\mid z /$, the controls' expert judgements concerning this sound, and the objective error analysis by the course teacher in the IPA task 3 (it should be remembered that this IPA task was executed by the participants without preparation and without any study aids).

As evident from Figure 3, 93\% of the participants assess the English consonant sound $|z|$ as difficult. The errors that involve the incorrect use of $/ z /$ by the participants account for $50 \%(/ \mathrm{s} /$ instead of $/ \mathrm{z} /)$ and $43 \%(/ \mathrm{z} /$ instead of $/ \mathrm{s} /)$ in the IPA Task 3. These findings appear to be in unison with the research study conducted by Haugen (1969), who posits that "The most persistent difficulty of Norwegian Americans is the inability to pronounce a proper $z$, especially at the end of words" (Haugen 1969, 48). 
objectively rated error /z/ instead of /s/ in

the participants' IPA task 3

objectively rated error /s/ instead of /z/ in the participants' IPA task 3

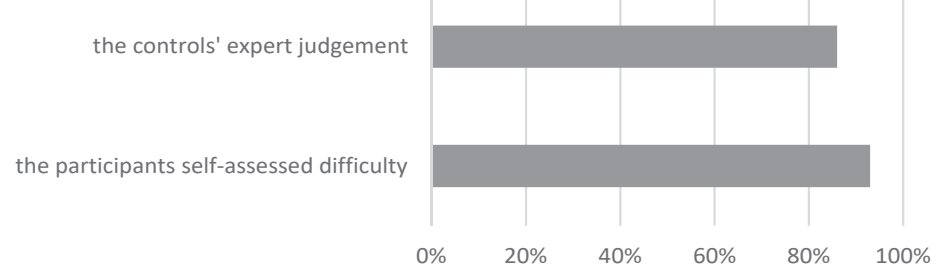

Figure 3. The English consonant sound /z/ in the participants' self-assessment, the controls' expert judgements and the objectively rated errors in IPA Task 3.

The participants' problems with the English consonant sound /z/ are evident in the context of cumulative errors in all IPA tasks, as seen in Figure 4 below. It follows from Figure 4 that in addition to the errors that involve $/ \mathrm{z} /$ and the $/ \mathrm{s} /-\mathrm{z} /$ contrast, the participants experience difficulties with the English short monophthong $/ \mathrm{N} /$, especially in the IPA Task 3, and with the English neutral vowel /ə/. Whilst the short monophthong $/ \Lambda /$ is absent from the Norwegian phonological system, the participants' self-assessment of $/ \Lambda /$ as problematic is not frequent (just $7 \%$ of the participants and none of the controls).

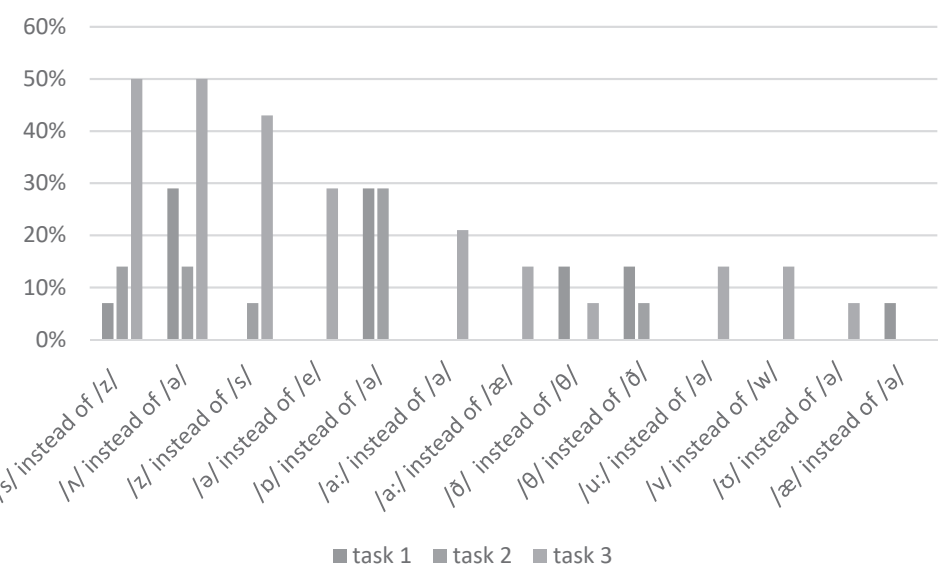

FIGURE 4. The percentage of errors in the IPA tasks per group of participants.

The participants' self-assessed difficulty with the English vowel/a/ appears more frequent ( $21 \%$ of the participants). Even though the participants' self-assessment of the difficulties related to /a/ seems less frequent in comparison with their selfassessment of other English sounds, especially /z/, it is, nevertheless, observed in 
Figure 4 that the majority of their mistakes are associated with the incorrect use of /ə/. These findings are illustrated by Figure 5, which is based upon the participants' self-assessment of the neutral vowel sound /ə/, the controls' expert judgements, and the objective error analysis by the course teacher in the IPA Task 3.

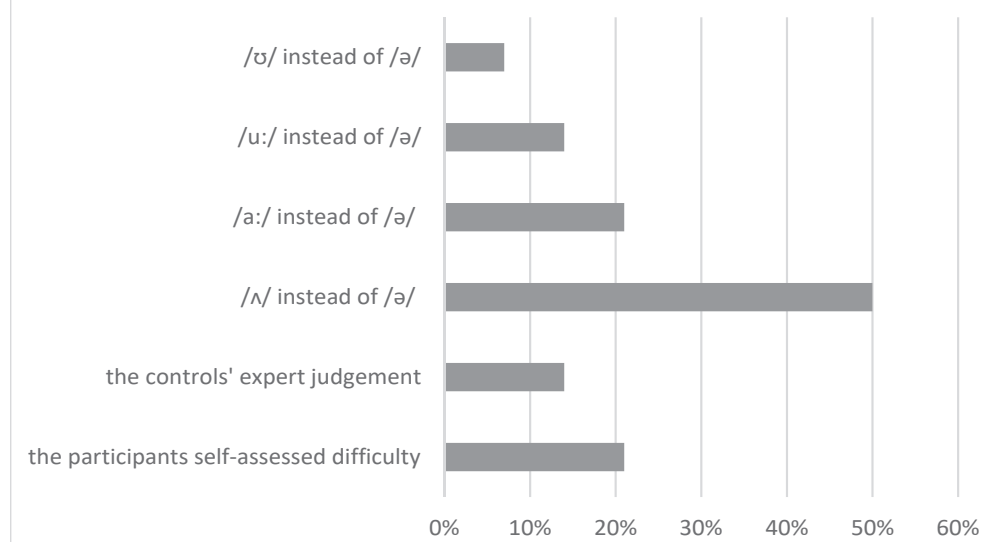

FigurE 5. The English neutral vowel sound /a/ in the participants' self-assessment, the controls' expert judgements and the objectively rated errors in the IPA Task 3.

It is evident from Figure 5 that the participants make mistakes in the IPA Task 3 that involve several instances of incorrect representation of the English neutral vowel /ə/. Arguably, these mistakes are reflective of the participants' problems with this sound that is absent from Norwegian. Notably, previous research (Cieślicka and Rojczyk 2017; Kapranov 2015; Lintunen 2013; Salimi, Kargar, and Zareian 2014; SzpyraKozłowska 2011; Szpyra-Kozłowska and Stasiak 2010) does not report EFL learners' problems concerning /ə/.

Other English sounds that are frequently evaluated by the participants and their controls as difficult are the interdental fricative consonants / $/$ and / $\theta /$ (see Table $5)$, which are not represented in the phonological system of the Norwegian language. This finding is in unison with the study by Salimi, Kargar and Zareian (2014), who also report EFL learners' self-assessed difficulties with /ð/ and / $\theta /$ due to their absence in the learners' L1. Additionally, this finding lends indirect support to Szpyra-Kozłowska (2011), who reports that Polish L1 intermediate EFL learners assess the combination of " $/ \theta /+$ a consonant" as challenging to pronounce. However, it is evident from the results in the present study that the participants' subjective evaluation of the problematicity of the sounds $/ \mathrm{d} /$ and $/ \theta /$ does not map onto multiple errors in IPA tasks. This finding is exemplified by Figure 6. 


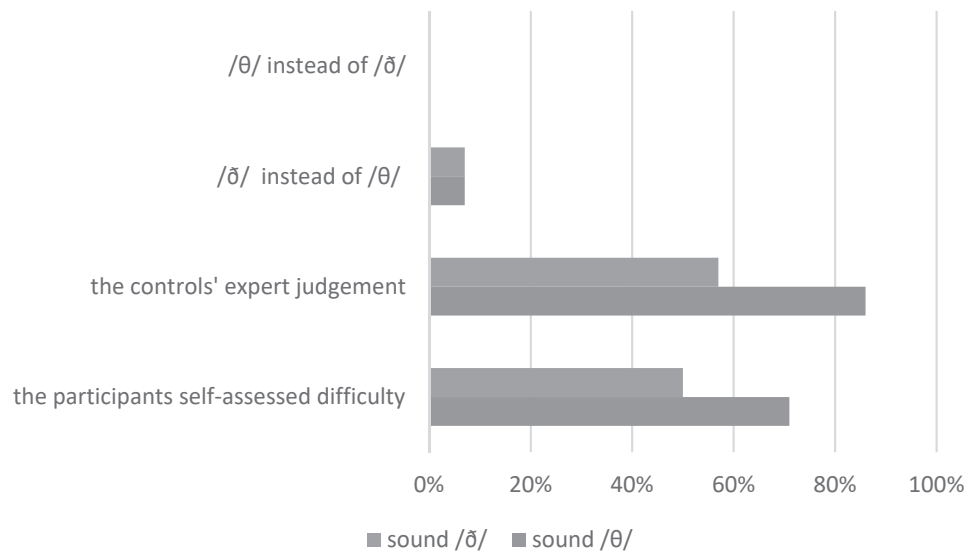

Figure 6 . The English inter-dental consonant sounds $/ \delta /$ and $/ \theta /$ in the participants' selfassessment, the controls' expert judgements and the objectively rated errors in the IPA Task 3.

It is observed in Figure 6 that $/ \delta /$ and $/ \theta /$ do not seem to be associated with substantial errors in the IPA Task 3 . However, it should be noted that the interdental fricative consonants $/ ð /$ and $/ \theta /$ have traditionally been regarded as problematic for Norwegian L1 speakers of English (Haugen 1969). Judging from the present data, the same argument can be applied to the approximant $/ \mathrm{w} /$, which is assessed as difficult by $29 \%$ of participants and $43 \%$ of controls. Similarly to /ð/ and / $/ \theta /$, the approximant $/ \mathrm{w} /$ is not involved in numerous mistakes in the IPA tasks $(14 \%$ errors in the IPA Task 3 and no errors in other tasks).

\section{Conclusions and Linguo-Didactic Implications}

The study established that the application of self-assessment to the identification of difficult English sounds by intermediate EFL learners whose L1 was Norwegian resulted in a repertoire of English sounds that was similar to that of the control group. Their shared repertoire of the problematic English sounds consisted of predominantly consonants $/ \mathrm{z} /, / \theta /, / \mathrm{\partial} / \mathrm{/} / \mathrm{s} /, / \mathrm{w} /, / \mathrm{t} / \mathrm{l} / \mathrm{v} /$, and one neutral vowel /ə/. Concurrently with those findings, it was found that whilst the participants and the controls assessed the sounds $/ ð /$ and $/ \theta /$ as highly problematic (e.g. $50 \%$ and $71 \%$ of the participants), the problematicity of those sounds did not map onto multiple errors in the IPA transcription tasks. In contrast, whereas the neutral vowel /ə/ was not assessed by all the participants as difficult, it caused a significant number of errors in the IPA tasks.

Since the study did not involve a substantial number of participants ( $\mathrm{N}$ of participants $=14$ and $\mathrm{N}$ of controls = 14, thus making it 28 in total), the results of the study should be treated with caution. Apart from the limited number of participants, another shortcoming in the study involved the lack of focus on the difficult-topronounce suprasegmental units. Arguably, an investigation of the Norwegian EFL 
learners' difficulties with individual English sounds and suprasegmentals would be desirable. Nevertheless, the present study has several linguo-didactic implications that would be relevant to those pre-service EFL teachers whose L1 is Norwegian. These linguo-didactic implications are as followed. First, pre-service EFL teachers whose L1 is Norwegian should be provided with possibilities to use self-assessment as a means of identifying their problems with pronunciation in English, especially by means of reflection upon difficult-to-pronounce English sounds. Second, Norwegian L1 pre-service EFL teachers should pay specific attention to the English $/ \mathrm{s} /-\mathrm{z} /$ contrast, and, in particular, to the voiced fricative consonant $/ \mathrm{z} /$. Third, Norwegian L1 pre-service EFL teachers should be made aware of the distinction between the short monophthong $/ \Lambda /$ and the neutral vowel sound / $/$ / in English.

\section{Acknowledgements}

The author of this article wants to acknowledge those pre- and in-service EFL teachers who took part in the study. Their participation is highly appreciated.

\section{References}

Boekaerts, Monique. 1997. "Self-Regulated Learning: A New Concept Embraced by Researchers, Policy Makers, Educators, Teachers, and Students." Learning and Instruction 7 (2): 161-86. https://doi. org/10.1016/S0959-4752(96)00015-1.

Boud, David. 2013. Enhancing Learning through Self-Assessment. London/NY: Routledge.

Cieślicka, Ewa Grażyna, and Arkadiusz Rojczyk. 2017. "Self-Reported vs. Self-Rated Pronunciation in a Non-Native Language." Theory and Practice of Second Language Acquisition 3 (2): 69-86.

Dettori, Giuliana, and Valentina Lupi. 2013. "Self-Observation and Shared Reflection to Improve Pronunciation in L2.” In International Handbook of Metacognition and Learning Technologies, edited by Roger Azevedo and Vincent Aleven, 615-25. Berlin: Springer.

Dlaska, Andrea, and Christian Krekeler. 2008. "Self-Assessment of Pronunciation." System 36 (4): 506-16. https://doi.org/10.1016/j.system.2008.03.003.

Dolosic, Haley. 2018. "An Examination of Self-Assessment and Interconnected Facets of Second Language Reading." Reading in a Foreign Language 30 (2): 189-208.

Flavell, John H. 1979. "Metacognition and Cognitive Monitoring: A New Area of Cognitive

Development Inquiry.” American Psychologist 34: 906-11.

IMDB. 2018a. "Skjelvet." Accessed 1 December 2018. https://www.imdb.com/title/tt6523720/.

—. 2018b. "The Predator." Accessed 1 December 2018. https://www.imdb.com/title/tt3829266/ plotsummary.

—. 2018c. "A Star is Born." Accessed 1 December 2018. https://www.imdb.com/title/ tt1517451/?ref_=nv_sr_1.

Harris, Michael. 1997. "Self-Assessment of Language Learning in Formal Settings." ELT Journal 51 (1): 12-20. https://doi.org/10.1093/elt/51.1.12.

Haugen, Einar Ingvald. 1969. The Norwegian Language in America. A Study in Bilingual Behavior. Bloomington: Indiana University Press.

Hopland, Amalie A. 2016. "Spoken English in the Classroom - A Study of Attitudes and Experiences of Spoken Varieties of English in English Teaching in Norway.” MA thesis, University of Bergen.

Huang, Hui-Ling, and James Radant. 2009. "Chinese Phonotactic Patterns and the Pronunciation Difficulties of Mandarin-Speaking EFL Learners.” The Asian EFL Journal Quarterly 11 (4): 115-34. 
Kapranov, Oleksandr. 2015. "Self-Evaluation of Speech Fluency in English as a Second Language by Korean Exchange Students Studying in Sweden.” In Language, Thought and Education: Exploring Networks, edited by Leszek Szymanski and Marek Kuczynski, 61-77. Zielona Gora: University of Zielona Gora.

Khamkhien, Attapol. 2010. "Thai Learners' English Pronunciation Competence: Lesson Learned from Word Stress Assignment.” Journal of Language Teaching \& Research 1 (6): 757-64. https://doi. org/10.4304/jltr.1.6.757-76.

Lappin-Fortin, Kerry, and B. J. Rye. 2014. "The Use of Pre-/Posttest and Self-Assessment Tools in a French Pronunciation Course.” Foreign Language Annals 47 (2): 300-320. https://doi.org/10.1111/flan.12083.

Lintunen, Pekka. 2013. "The Effect of Phonetic Knowledge on Evaluated Pronunciation Problems." In Proceedings of the Phonetics Teaching and Learning Conference, edited by John A. Maidment, 55-58. London: UCL.

Liu, Huan, and Cindy Brantmeier. 2019. “'I Know English': Self-Assessment of Foreign Language Reading and Writing Abilities among Young Chinese Learners of English.” System 80: 60-72. https://doi. org/10.1016/j.system.2018.10.013.

Moen, Per. 1988. "The English Pronunciation of Norwegian-Americans in Four Midwestern States." American Studies in Scandinavia 20 (2): 105-21.

Nilsen, Thor Sigurd, and Kåre N. Rugesæter. 2015. English Phonetics for Teachers. Oslo: Fagbokforlaget.

Ohata, Kota. 2004. "Phonological Differences between Japanese and English: Several Potentially Problematic Areas of Pronunciation for Japanese ESL/EFL Learners." The Asian EFL Journal 6.

Oscarson, Mats. 2013. "The Challenge of Student Self-Assessment in Language Education." Voices in Asia Journal 1 (1): 1-14.

—. 1989. "Self-Assessment of Language Proficiency: Rationale and Applications." Language Testing 6 (1): 1-13. https://doi.org/10.1177\%2F026553228900600103.

Saito, Kazuya. 2014. "Experienced Teachers' Perspectives on Priorities for Improved Intelligible Pronunciation: The Case of Japanese Learners of English." International Journal of Applied Linguistics 24 (2): 250-77. https://doi.org/10.1111/ijal.12026.

—. 2011. "Identifying Problematic Segmental Features to Acquire Comprehensible Pronunciation in EFL Settings: The Case of Japanese Learners of English." RELC Journal 42 (3): 363-78. https://doi. org/10.1177\%2F0033688211420275.

Salimi, Marjan, Ali A. Kargar, and Arash Zareian. 2014. "Self-Assessment of Pronunciation and Its Impact on EFL Learners' Pronunciation Ability." International Journal of Language Learning and Applied Linguistics World 6 (4): 605-22.

SPSS. 2016. IBM SPSS Statistics for Windows, Version 24.0. Armonk, NY: IBM Corp.

Sweet, Gabriela, Sara Mack, and Anna Olivero-Agney. 2019. "Where Am I? Where Am I Going, and How Do I Get There?: Increasing Learner Agency Through Large-Scale Self-Assessment in Language Learning." In Foreign Language Proficiency in Higher Education, edited by Paula Winke and Susan M. Gass, 175-95. Switzerland: Springer.

Szpyra-Kozłowska, Jolanta. 2011. "Phonetically Difficult Words in Intermediate Learners' English.” In Speaking and Instructed Foreign Language Acquisition, edited by Mirosław Pawlak, Ewa WaniekKlimczak, and Jan Majer, 286-99. Bristol: Multilingual Matters.

Szpyra-Kozłowska, Jolanta, and Sławomir Stasiak. 2010. "From Focus on Sounds to Focus on Words in English Pronunciation Instruction.” Research in Language 8: 1-12. https://doi.org/10.2478/v10015-010-0012-7.

Szyszka, Magdalena. 2011. "Foreign Language Anxiety and Self-Perceived English Pronunciation Competence." Studies in Second Language Learning and Teaching 2 (1): 283-300.

The Council of Europe. 2011. Common European Framework of Reference for Languages: Learning, Teaching, Assessment (CEFR). Accessed 1 January 2019. https://www.coe.int/en/web/common-europeanframework-reference-languages.

Thomas, Catherine. 2014. "Meeting EFL Learners Halfway by Using Locally Relevant Authentic Materials." English Teaching Forum 52 (3): 14-23.

Trofimovich, Pavel, Talia Isaacs, Sara Kennedy, and Kazuya Saito. 2016. "Flawed Self-Assessment: Investigating Self-And Other-Perception of Second Language Speech.” Bilingualism: Language and Cognition 19 (1): 122-40. 